\title{
Sensitivity of Certain Porcine and Bovine Mycoplas- mas to Antimicrobial Agents in a Liquid Medium Test Compared to a Disc Assay
}

\author{
By N. F. Friis ${ }^{l}$ and J. Szancer ${ }^{2}$
}

'Danish Veterinary Laboratory, Copenhagen, and ${ }^{2}$ Leo Pharmaceutical Products, Ballerup, Denmark.

\begin{abstract}
Friis, N.F. and J. Szancer: Sensitivity of certain porcine and bovine mycoplasmas to antimicrobial agents in a liquid medium test compared to a disc assay. Acta vet. scand. 1994, 35, 389-394. - The sensitivity of some porcine and bovine mycoplasmas to potent antimicrobial agents was examined. Minimal inhibitory concentration (MIC) values were estimated for M. hyosynoviae, M. hyopneumoniae, $M$. dispar and $M$. bovis against enrofloxacin, lincomycin, tetracycline, tiamulin and tylosin, in a liquid medium test and in a disc assay. All 6 examined strains of each species and the respective type strains were significantly inhibited. The greatest sensitivity was noted for tiamulin against strains of $M$. hyosynoviae with a final $\mathrm{MIC}_{50}$ broth value of $0.025 \mu \mathrm{g} \mathrm{ml}^{-1}$ and disc value of $0.03 \mu \mathrm{g}$ per disc. Enrofloxacin was found very potent against M.hyopneumoniae with a final $\mathrm{MIC}_{50}$ of $0.025 \mu \mathrm{g} \mathrm{ml}^{-1}$ and $0.1 \mu \mathrm{g}$ per disc, and for $M$. dispar with $0.05 \mu \mathrm{g} \mathrm{ml}^{-1}$ and $0.03 \mu \mathrm{g}$ per disc.

Most disc assay estimates in $\mu \mathrm{g}$ per disc were similar to or moderately greater than corresponding final broth figures in $\mu \mathrm{g} \mathrm{ml}^{-1}$. It may be possible to convert observed disc assay values into representative final broth MIC values for use in the clinic.
\end{abstract}

antibiotic; bovis; dispar; hyopneumoniae; hyosynoviae; lincomycin; quinolone; tetracycline; tiamulin; tylosin.

\section{Introduction}

In the search for effective antimicrobial therapy of mycoplasma infections in domesticated animals many agents have been examined, both in live animals (Hannan et al. 1982, Burch \& Goodwin 1984, Ball \& McCaughey $1985)$ and in vitro, usually in liquid medium (Williams 1978, Stipkovits et al. 1984, Cooper et al. 1993) but also using solid agar with the antimicrobial compounds incorporated (Hannan et al. 1989, ter Laak et al. 1991) or applied in dried paper discs (Wachowski \& Kirchhoff 1986).

From the various information it appears that many examined compounds possess a good suppressive effect on the replication of the mycoplasmas, especially in the in vitro studies, although some variation in the minimal inhibitory concentration (MIC) values is apparent. These differences probably reflect minor diversities in the performance of the examinations. Notably higher MIC figures seem to result from work with the agents incorporated in dried paper discs placed on preseeded agar (Wachowski \& Kirchhoff 1986).

Among compounds for which very low in vitro MIC values have been reported are fluoroquinolones, tiamulin and tylosin, but also lincomycin, macrolides and tetracyclines are often remarkably effective.

The aim of the present work has been to examine the inhibitory effect of some antimicrobial compounds on the in vitro growth of 
pathogenic mycoplasmas from swine and cattle. In addition initial and final MIC values for agents dissolved in liquid medium have been determined and compared with the results obtained from disc diffusion tests, with the aim of providing a basis for routine antimicrobial sensitivity estimation.

\section{Materials and methods}

Design of the experiment

Antimicrobial agents were selected among the compounds usually recommended for treatment of infections with mycoplasmas in cattle and swine. The minimal inhibitory concentrations (MIC) were estimated as initial and final readings against the more important mycoplasma species cultivated both in liquid and on solid medium.

\section{Strains of mycoplasma}

The type strain and 6 Danish newer field isolates of each of 4 mycoplasma species were examined: the bovine $M$. dispar, type strain 462/2 and $M$. bovis, type strain PG45; the porcine $M$. hyopneumoniae, type strain "J" and $M$. hyosynoviae, type strain S16. The isolates originated from different farms (except 1 pig farm with 2 strains of $M$. hyosynoviae). The field strains were filtered through a $0.45 \mu \mathrm{m}$ membrane and cloned once from a colony on solid medium and were used in 6th-10th passage. They were kept at $-80^{\circ} \mathrm{C}$.

\section{Antimicrobial agents}

The agents selected were the chemotherapeuticum Enrofloxacin (a fluoroquinolone compound, Bayer Germany), and the antibiotics Lincomycin hydrochloride (Sigma L-6004), Tetracycline hydrochloride (Sigma T-7660), Tiamulin hydrogen fumarate (Leo Pharmaceutical Products, Ballerup, Denmark), and Tylosin tartrate (Elanco). The 4 antibiotics were dissolved in distilled water and enrofloxacin in $5 \mathrm{mmol} / 1 \mathrm{HCl}$ at $40^{\circ} \mathrm{C}$. They were added to liquid medium making serial approx. 2 -fold dilutions in $\mu \mathrm{g}$ per $\mathrm{ml}$, and to discs at approx. 3-fold dilutions in $\mu \mathrm{g}$ per disc, which were dried overnight at $37^{\circ} \mathrm{C}$. Antibiotic Assay discs, $6.0 \mathrm{~mm}$ Whatman ${ }^{\circledR}$ were used.

\section{Sensitivity experiment}

A medium evolved for $M$. hyopneumoniae was used for this species and for $M$. dispar, and a Hayflick's type of medium was used for $M$. bovis and with added arginine/mucin for M. hyosynoviae (Friis et al. 1991). Solid medium was prepared from the former medium only. The liquid medium test was performed in tubes containing $1.8 \mathrm{ml}$ of medium.

Mycoplasma stock cultures from $-80^{\circ} \mathrm{C}$ were inoculated as 10 -fold dilutions to $10^{-4}$ for each antimicrobial concentration and read visually for initial and final MIC values using tubes seeded with $10^{2}$ to $10^{4}$ colour changing units. Initial reading was done after 2-4 days and final reading after 7-10 days when no progression had taken place over 2 days. Distinct colour

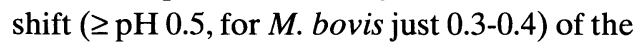
phenol red indicator in the medium was regarded as a positive reaction for growth, i.e. from yellow to red-bluish in cultures of $M$. hyosynoviae and from red to yellow in the 3 remaining species. Minimal inhibitory concentration (MIC) was determined as the lowest concentration indicating inhibition of growth as compared to controls without antimicrobials.

The solid medium test was performed using $60 \mathrm{~mm}$ petri dishes with just 1 antimicrobialcontaining disc per plate and were incubated at $37^{\circ} \mathrm{C}$ in an atmosphere of $5-10$ per cent $\mathrm{CO}_{2}$ until growth. Plates with a non-confluent culture yielding numerous, but still distinct colonies were used. A zone from the edge of discs to the rim of normal colonies measuring at le- 
Table 1. Antimicrobial sensitivity MIC values with porcine and bovine mycoplasmas against compounds in liquid medium and in dried discs.

\begin{tabular}{|c|c|c|c|c|c|c|c|c|c|c|c|c|c|c|c|}
\hline & \multicolumn{3}{|c|}{ Tiamulin } & \multicolumn{3}{|c|}{ Lincomycin } & \multicolumn{3}{|c|}{ Tetracycline } & \multicolumn{3}{|c|}{ Enrofloxacin } & \multicolumn{3}{|c|}{ Tylosin } \\
\hline & $\mathrm{i}$ & f & d & $\mathrm{i}$ & f & d & $\mathrm{i}$ & $\mathrm{f}$ & d & $\mathrm{i}$ & f & d & $\mathrm{i}$ & f & d \\
\hline \multicolumn{16}{|c|}{ M. hyosynoviae } \\
\hline Type strain & 0.0025 & 0.025 & 0.03 & 0.10 & 0.50 & 0.3 & 0.10 & 0.25 & 3.0 & 0.25 & 0,5 & 1.0 & 0.025 & 0.050 & 0.03 \\
\hline 125 & 0.0025 & 0.050 & 0.03 & 0.05 & 1.00 & 1.0 & 0.25 & 0.50 & 10.0 & 0.50 & 1.0 & 1.0 & 0.025 & 0.025 & 0.10 \\
\hline 157 & 0.0025 & 0.025 & 0.10 & 0.10 & 1.00 & 1.0 & 0.25 & 1.00 & 3.0 & 0.50 & 1.0 & 1.0 & 0.025 & 0.050 & 0.10 \\
\hline 561 & 0.0050 & 0.025 & 0.10 & 0.05 & 0.50 & 1.0 & 0.25 & 1.00 & 10.0 & 0.25 & 0.5 & 1.0 & 0.250 & 2.500 & 1.00 \\
\hline 702 & 0.0025 & 0.025 & 0.03 & 0.10 & 0.50 & 1.0 & 1.00 & 2.50 & 10.0 & 0.50 & 1.0 & 1.0 & 0.500 & 2.500 & 0.30 \\
\hline 712 & 0.0025 & 0.010 & 0.01 & 0.10 & 0.25 & 0.1 & 0.25 & 1.00 & 1.0 & 0.50 & 1.0 & 1.0 & 0.025 & 0.050 & 0.10 \\
\hline 713 & 0.0025 & 0.025 & 0.01 & 0.05 & 0.25 & 0.3 & 0.25 & 1.00 & 10.0 & 0.50 & 1.0 & 1.0 & 0.025 & 0.050 & 0.10 \\
\hline \multicolumn{16}{|c|}{ M. hyopneumoniae } \\
\hline Type strain & 0.025 & 0.10 & 1.0 & 0.25 & 0.50 & 1.0 & 0.050 & 0.250 & 0.30 & 0.025 & 0.100 & 0.10 & 0.100 & 0.25 & 1.00 \\
\hline 143 & 0.025 & 0.05 & 0.3 & 0.25 & 0.50 & 1.0 & 0.050 & 0.100 & 1.00 & 0.025 & 0.050 & 0.10 & 0.025 & 0.10 & 0.30 \\
\hline 198 & 0.050 & 0.10 & 0.3 & 0.25 & 0.25 & 1.0 & 0.010 & 0.025 & 0.10 & 0.025 & 0.025 & 0.03 & 0.050 & 0.10 & 0.30 \\
\hline 228 & 0.050 & 0.10 & 0.3 & 0.25 & 0.25 & 1.0 & 0.025 & 0.025 & 0.10 & 0.025 & 0.025 & 0.10 & 0.100 & 0.25 & 1.00 \\
\hline 721 & 0.025 & 0.05 & 0.3 & 0.25 & 0.50 & 1.0 & 0.025 & 0.050 & 0.10 & 0.025 & 0.025 & 0.10 & 0.025 & 0.10 & 1.00 \\
\hline 785 & 0.050 & 0.10 & 0.3 & 0.25 & 0.50 & 1.0 & 0.025 & 0.025 & 0.10 & 0.025 & 0.025 & 0.10 & 0.025 & 0.10 & 1.00 \\
\hline 806 & 0.025 & 0.10 & 0.3 & 0.25 & 0.25 & 1.0 & 0.010 & 0.025 & 0.10 & 0.025 & 0.050 & 0.10 & 0.025 & 0.10 & 0.30 \\
\hline \multicolumn{16}{|l|}{ M. dispar } \\
\hline Type strain & 0.025 & 0.1 & 0.3 & 0.25 & 0.50 & 3.0 & 0.050 & 0.10 & 0.3 & 0.025 & 0.05 & 0.03 & 0.100 & 0.250 & 1.0 \\
\hline 31 & 0.025 & 0.1 & 1.0 & 0.10 & 0.50 & 3.0 & 0.025 & 0.05 & 0.1 & 0.025 & 0.05 & 0.10 & 0.025 & 0.050 & 0.3 \\
\hline 201 & 0.050 & 0.1 & 0.3 & 0.10 & 0.50 & 3.0 & 0.100 & 0.25 & 0.3 & 0.050 & 0.05 & 0.03 & 0.025 & 0.100 & 0.3 \\
\hline 216 & 0.050 & 0.1 & 1.0 & 0.25 & 0.50 & 3.0 & 0.100 & 0.25 & 0.3 & 0.025 & 0.05 & 0.03 & 0.025 & 0.050 & 0.3 \\
\hline 228 & 0.050 & 0.1 & 0.3 & 0.25 & 0.50 & 0.3 & 0.050 & 0.05 & 0.1 & 0.025 & 0.05 & 0.10 & 0.025 & 0.100 & 0.1 \\
\hline 232 & 0.025 & 0.1 & 1.0 & 0.25 & 0.25 & 3.0 & 0.100 & 0.25 & 0.3 & 0.025 & 0.05 & 0.03 & 0.025 & 0.025 & 0.3 \\
\hline 285 & 0.050 & 0.1 & 0.3 & 0.25 & 0.50 & 1.0 & 0.100 & 0.25 & 0.3 & 0.025 & 0.05 & 0.03 & 0.100 & 0.250 & 1.0 \\
\hline \multicolumn{16}{|l|}{ M. bovis } \\
\hline Type strain & 0.05 & 0.25 & 0.3 & 0.5 & 1.0 & 3.0 & 0.05 & 0.25 & 0.3 & 0.1 & 0.25 & 0.3 & 0.25 & 0.5 & 0.3 \\
\hline 9 & 0.05 & 0.25 & 0.3 & 0.5 & 2.5 & 3.0 & 1.00 & 2.50 & 1.0 & 0.1 & 0.25 & 0.3 & 0.50 & 2.5 & 3.0 \\
\hline 11 & 0.10 & 0.50 & 0.3 & 1.0 & 2.5 & 3.0 & 0.50 & 5.00 & 1.0 & 0.1 & 0.25 & 0.3 & 0.50 & 5.0 & 10.0 \\
\hline 12 & 0.05 & 0.50 & 1.0 & 1.0 & 2.5 & 1.0 & 0.50 & 2.50 & 3.0 & 0.1 & 0.25 & 0.3 & 1.00 & 5.0 & 3.0 \\
\hline 23 & 0.05 & 0.50 & 1.0 & 0.5 & 2.5 & 3.0 & 1.00 & 2.50 & 3.0 & 0.1 & 0.25 & 0.3 & 1.00 & 1.0 & 3.0 \\
\hline 317 & 0.10 & 0.50 & 0.3 & 0.5 & 2.5 & 1.0 & 0.50 & 2.50 & 3.0 & 0.1 & 0.25 & 0.1 & 2.50 & 2.5 & 1.0 \\
\hline 344 & 0.10 & 0.25 & 0.3 & 0.5 & 2.5 & 3.0 & 1.00 & 2.50 & 10.0 & 0.1 & 0.25 & 0.1 & 0.50 & 2.5 & 1.0 \\
\hline
\end{tabular}

$\mathrm{i}, \mathrm{f}=$ initial and final $\mu \mathrm{g} \mathrm{ml^{-1 }}$ values; $\mathrm{d}=$ disc values in $\mu \mathrm{g}$ per disc.

Table $2 . \mathrm{MIC}_{50}$ values for mycoplasmas with agents in liquid medium and in discs.

\begin{tabular}{|c|c|c|c|c|c|c|c|c|c|c|c|c|c|c|c|}
\hline & \multicolumn{3}{|c|}{ Tiamulin } & \multicolumn{3}{|c|}{ Lincomycin } & \multicolumn{3}{|c|}{ Tetracycline } & \multicolumn{3}{|c|}{ Enrofloxacin } & \multicolumn{3}{|c|}{ Tylosin } \\
\hline & $\mathrm{i}$ & $f$ & $\mathrm{~d}$ & $\mathrm{i}$ & $f$ & $\bar{d}$ & $\mathrm{i}$ & $f$ & $\mathrm{~d}$ & $\mathrm{i}$ & $f$ & $\mathrm{~d}$ & $\mathrm{i}$ & $\mathrm{f}$ & $\mathrm{d}$ \\
\hline M. hyopneumoniae, type & 0.025 & 0.1 & 1.0 & 0.25 & 0.5 & 1.0 & 0.05 & 0.25 & 0.3 & 0.025 & 0.1 & 0.1 & 0.1 & 0.25 & 1.0 \\
\hline 6 field strains & 0.025 & 0.1 & 0.3 & 0.25 & 0.25 & 1.0 & 0.025 & 0.025 & 0.1 & 0.025 & 0.025 & 0.1 & 0.025 & 0.1 & 0.3 \\
\hline M. hyosynoviae, type & 0.0025 & 0.025 & 0.03 & 0.1 & 0.5 & 0.3 & 0.1 & 0.25 & 3.0 & 0.25 & 0.5 & 1.0 & 0.025 & 0.05 & 0.03 \\
\hline 6 field strains & 0.0025 & 0.025 & 0.03 & 0.05 & 0.5 & 1.0 & 0.25 & 1.0 & 10.0 & 0.5 & 1.0 & 1.0 & 0.025 & 0.05 & 0.1 \\
\hline$M$. dispar, type & 0.025 & 0.1 & 0.3 & 0.25 & 0.5 & 3.0 & 0.05 & 0.1 & 0.3 & 0.025 & 0.05 & 0.03 & 0.1 & 0.25 & 1.0 \\
\hline 6 field strains & 0.05 & 0.1 & 0.3 & 0.25 & 0.5 & 3.0 & 0.1 & 0.25 & 0.3 & 0.025 & 0.05 & 0.03 & 0.025 & 0.05 & 0.3 \\
\hline M. bovis, type & 0.05 & 0.25 & 0.3 & 0.5 & 1.0 & 3.0 & 0.05 & 0.25 & 0.3 & 0.1 & 0.25 & 0.3 & 0.25 & 0.5 & 0.3 \\
\hline 6 field strains & 0.05 & 0.5 & 0.3 & 0.5 & 2.5 & 3.0 & 0.5 & 2.5 & 3.0 & 0.1 & 0.25 & 0.3 & 0.5 & 2.5 & 3.0 \\
\hline
\end{tabular}

$\mathrm{i}, \mathrm{f}=$ initial and final $\mu \mathrm{g} \mathrm{ml}^{-1}$ values; $\mathrm{d}=$ disc values in $\mu \mathrm{g}$ per disc. 
ast $5 \mathrm{~mm}$ with total or near-total inhibition was noted as sensitive. Reading was done after 3-5 days of incubation.

$\mathrm{MIC}_{50}$ figures were calculated from individual readings as the smallest concentration able to inhibit at least $50 \%$ of the field strains of a single species.

\section{Results}

All 5 examined antimicrobial compounds (Table 1) were able to inhibit the replication of each of the 7 strains belonging to the 4 species in a concentration range of 0.0025 to 5.0 $\mu \mathrm{g} / \mathrm{ml}$. At the initial reading performed after 2-3 days in liquid medium, the MIC values for tiamulin was $0.0025 \mu \mathrm{g} \mathrm{ml}^{-1}$ with strains of $M$. hyosynoviae and approx. 10-fold higher with strains of $M$. hyopneumoniae and $M$. dispar. Initial MIC for enrofloxacin and tylosin was found at $0.025 \mu \mathrm{g} \mathrm{ml}^{-1}$ for many strains of $M$. hyopneumoniae and $M$. dispar. Also against $M$. hyosynoviae similar MIC values were noted for tylosin. With lincomycin initial MIC was usually 0.1 to $0.5 \mu \mathrm{g} \mathrm{ml}^{-1}$. For $M$. bovis initial MIC values were found 5-10 times higher for all antimicrobials than for most other strains. Final MIC values in liquid medium were read after 7-10 days and in most cases found 25 times those of the initial readings.

The MIC values for compounds in dried paper discs placed on preseeded agar were expressed as $\mu \mathrm{g}$ per disc and as such were usually found similar to or up to 5 times higher than the final MIC liquid medium figures expressed as $\mu \mathrm{g} \mathrm{ml}^{-1}$.

$\mathrm{MIC}_{50}$ concentrations expressing inhibition of at least 3 of the 6 field strains are given in Table 2 together with the values for the type strains. For $M$. bovis type strain, the initial, final and disc figures obtained with tetracycline and tylosin were up to 10 times lower than the field strain values.

\section{Discussion}

Some important antimicrobial agents with reported inhibitory effect on the replication of mycoplasmas were tested against a fairly low number of strains belonging to pathogenic bovine and porcine species (Cooper et al. 1993, ter Laak et al. 1991). All the examined compounds, enrofloxacin, lincomycin, tetracycline, tiamulin and tylosin showed a distinct effect on M. hyosynoviae and M. hyopneumoniae from swine, and $M$. dispar and $M$. bovis from cattle. As such the obtained results concord with earlier in vitro findings by others (Allan \& Pirie 1981, Goodwin 1985, Hannan et al. 1989, Takahashi et al. 1978, Truscott \& Ruhnke 1984).

The greatest potency noted throughout the present work was for tiamulin against $M$. hyosynoviae; a finding which corresponds to in vitro results obtained by Hannan et al. (1989) and also to experience from veterinary therapeutic work (Burch \& Goodwin 1984, Madeiros 1984). The quinolone compound enrofloxacin was found remarkably effective against $M$. hyopneumoniae and $M$. dispar as was likewise found by Cooper et al. (1993) with another quinolone derivative, danofloxacin. Intraspecies strain variability in sensitivity was generally found moderate, especially for tiamulin and enrofloxacin. Such a feature may depend on little liability for development of resistance, but may also derive from limited use in therapy. For tylosin some strains among the examined species showed a reduced sensitivity. According to Cooper et al. (1993), this phenomenon may reflect an intensive medical use during many years.

The final MIC values as noted in liquid medium may be of special interest in the veterinary clinic, but the estimations are too laborious for routine work. As in the present work the final broth $\mathrm{MIC}_{50}$ values in $\mu \mathrm{g} \mathrm{ml}^{-1}$ were found similar to or just moderately lower than 
the disc $\mathrm{MIC}_{50}$ values in $\mu \mathrm{g} / \mathrm{disc}$, it is suggested that the formula

$$
\mathrm{Fb}_{\mathrm{c}}=\frac{\mathrm{Fb}_{\mathrm{kn}} \times \mathrm{Do}}{\mathrm{D}_{\mathrm{kn}}}
$$

be used to calculate the corresponding final broth MIC $\left(\mathrm{Fb}_{\mathrm{c}}\right)$ from an observed disc method MIC (Do) by using the known final broth $\mathrm{MIC}_{50}\left(\mathrm{Fb}_{\mathrm{kn}}\right)$ and disc $\mathrm{MIC}_{50}\left(\mathrm{D}_{\mathrm{kn}}\right)$ values (Table 2). Finally, in another way, a corresponding MIC figure might be derived from a disc-dose-depending curve plotted in a system of co-ordinates.

\section{References}

Allan EM, Pirie HM: In vitro activity of tiamulin against bovine respiratory tract mycoplasmas. Res. vet. Sci. 1981, 31, 174-176.

Ball HJ, McCaughey WJ: Experimental intramuscular inoculation of tiamulin and oxytetracycline in the elimination of ureaplasmas from sheep. Vet. Rec. 1985, 117, 640-641.

Burch DGS, Goodwin RFW: Use of tiamulin in a herd of pigs seriously affected with Mycoplasma hyosynoviae arthritis. Vet. Rec. 1984, 115, 594595.

Cooper AC, Fuller JR, Fuller MK, Whittlestone P, Wise $D R$ : In vitro activity of danofloxacin, tylosin and oxytetracycline against mycoplasmas of veterinary importance. Res. vet. Sci. 1993, 54, 329-334.

Friis NF, Ahrens P, Larsen H: Mycoplasma hyosynoviae isolation from the upper respiratory tract and tonsils of pigs. Acta vet. scand. 1991, 32, 425429.

Goodwin RFW: In vitro activity of tiamulin against porcine mycoplasmas. Res. vet. Sci. 1985, 38, 124-125.

Hannan PCT, Bhogal BS, Fish JP: Tylosin tartrate and tiamulin effects on experimental piglet pneumonia induced with pneumonic pig lung homogenate containing mycoplasmas, bacteria and viruses. Res. vet. Sci. 1982, 33, 76-88.

Hannan PCT, O'Hanlon PJ, Rogers NH: In vitro evaluation of various quinolone antibacterial agents against veterinary mycoplasmas and porcine respiratory bacterial pathogens. Res. vet. Sci. 1989, 46, 202-211.
Madeiros CA: Mycoplasma hyosynoviae treatment in pigs. Vet. Rec. 1984, 115, 446.

Stipkovits L, Varga Z. Laber G, Böckmann J: A comparison of the effect of tiamulin hydrogen fumarate and tylosin tartrate on mycoplasmas of ruminants and some animal ureaplasmas. Vet. Microbiol. 1984, 9, 147-153.

Takahashi K, Kuniyasu C, Yoshida Y, Momotani E: Sensitivity in vitro to macrolide antibiotics and tetracyclines of Mycoplasma hyopneumoniae isolated from pneumonic porcine lungs. Nat. Inst. Anim. Hlth. Quart. 1978, 18, 41-42.

Ter Laak EA, Pupers A, NoordergraafJH, Schoevers EC, Verheijden JHM: Comparison of methods for in vitro testing of susceptibility of porcine mycoplasma species to antimicrobial agents. Antimicrob. Agents Chemother. 1991, 35, 228233.

Truscott $R B$, Ruhnke $H L$ : The effect of antibiotics against bovine mycoplasmas and ureaplasmas. Can. J. comp. Med. 1984, 48, 171-174.

Wachowski Ch, Kirchhoff $H$ : Untersuchung der Empfindlichkeit von Mycoplasma bovis Feldstämmen gegenüber verschiedenen Antibiotica und Chemotherapeutica. (Examination of the sensitivity of field isolates of Mycoplasma bovis to several antibiotics and chemotherapeutics). Berl. Münch. Tierärztl. Wschr. 1986, 99, 041-044.

Williams PP: In vitro susceptibility of Mycoplasma hyopneumoniae and Mycoplasma hyorhinis to fifty-one antimicrobial agents. Antimicrob. Agents Chemother. 1978, 14, 210-213.

\section{Sammendrag}

Følsomhed for antimicrobielle stoffer hos visse svineog kvagmykoplasmer unders $\emptyset$ gt $i$ flydende medium og sammenlignet til en disk metode.

Nogle vigtige svine- og kvægmykoplasmer blev unders $\emptyset \mathrm{gt}$ for følsomhed over for specielt udvalgte, potente antimikrobielle forbindelser. Den laveste hæmmende koncentration (MIC værdi) blev bestemt for 6 nye isolater samt typestammen af de porcine arter, M. hyosynoviae og M. hyopneumoniae, samt de bovine arter $M$. dispar og $M$. bovis, over for enrofloxacin, lincomycin, tetracyclin, tiamulin og tylosin. Der blev anvendt både en test i flydende medium med tidlig og slut MIC registrering samt en disk metode.

Alle isolater samt typestammerne fandtes tydeligt følsomme under begge fors $\emptyset$ gsbetingelser. Den største følsomhed blev registreret for tiamulin over 
for $M$. hyosynoviae, hvor der fandtes en slut $\mathrm{MIC}_{50}$ værdi på $0.025 \mu \mathrm{g}$ pr. ml og en disk værdi på $0.03 \mu \mathrm{g}$ pr. disk. Også enrofloxacin fandtes bemærkelsesværdigt aktivt over for $M$. hyopneumoniae med slut $\mathrm{MIC}_{50}$ på $0.025 \mu \mathrm{g}$ pr. ml og $0.1 \mu \mathrm{g}$ pr. disk og over for M. dispar på $0.05 \mu \mathrm{g}$ pr. $\mathrm{ml}$ og $0.03 \mu \mathrm{g}$ pr. disk. I fors $\emptyset \mathrm{g}$ med enrofloxacin, lincomycin og tiamulin fandtes kun mindre stammevariation inden for mykoplasmaarterne, medens spredningen var noget større for tetracyclin og tylosin; en forskel, som kunne afspejle intensiteten i brugen over årene.

I de fleste fors $\emptyset \mathrm{g}$ fandtes disk værdierne i $\mu \mathrm{g}$ pr. disk på niveau med eller moderat højere end de tilsvarende slutværdier i $\mu \mathrm{g}$ pr. ml. Det synes derfor muligt at konvertere observerede disk assay værdier til repræsentative slutværdier i $\mu \mathrm{g}$ pr. ml ved hjælp af en simpel omregningsfaktor med henblik på udnyttelse i klinikken.

(Received June 6, 1994; accepted August 23, 1994).

Reprints may be requested from: N.F. Friis, Danish Veterinary Laboratory, Bülowsvej 27, DK-1790 Copenhagen V, Denmark. 